\title{
The Effectiveness of Online Website-Based New Student Admissions (PPDB)
}

\author{
Dede Supendi ${ }^{1,2^{*}}$, Aan Komariah ${ }^{1}$, Dedy Achmad Kurniady ${ }^{1}$ \\ ${ }^{1}$ Educational Administration Department, ${ }^{2}$ STAI DR KHEZ Muttaqien Purwakarta \\ ${ }^{1}$ Universitas Pendidikan Indonesia \\ ${ }^{1}$ Bandung, ${ }^{2}$ Purwakarta, Indonesia \\ *dede.supendi82@gmail.com
}

\begin{abstract}
The purpose of this research is to see the effectiveness of the implementation of web-based new student admissions. The research method used is descriptive qualitative which is carried out in public junior high schools in Purwakarta Regency. The results showed that the application of web-based online new student admissions (PPDB) has been running effectively but there are still obstacles and shortcomings in its implementation. The web-based online PPDB implementation is taken through the Zoning Path, the Parent / Trustee Transfer Path and the Achievement Path. The conclusion is that it is necessary to improve school services in managing this websitebased PPDB by planning to fulfill the needs of the internet and ICT facilities for parents and the community.
\end{abstract}

Keywords-effectiveness, online new student admission, online website base

\section{INTRODUCTION}

The position of technology in society is no longer a supplement but has become a basic necessity. Technology does not only touch the general order of society in everyday life, but this also applies to education. The world of education is equally successful in advancing the concept of education by using an ICT approach. The existence of an information system in education is one component that cannot be separated from a series of educational activities [1]

Information technology plays a role in changing the completion of a job to increase work efficiency and increase the creativity and activity of employees who have good skills and abilities. In the era of revolution 4.0, education is required to be able to develop everything quickly and responsively in decision making so that with information technology, many educational institutions use a computerized system as a tool to facilitate work and make educational institutions of high quality. In every educational institution such as a school, it is always faced with problems in carrying out an activity. Starting from very simple problems to quite complex problems. All of that requires attention and deeper handling so that these problems can be resolved [2].

The admission of new students (PPDB) is the gateway to educational services in each educational unit. In the past few years, the registration of new students is still using the manual method, namely by filling in the form using a sheet provided by the committee, because using handwriting will allow the committee to have difficulty reading. In addition, in the process of making the admission selection report, new students take longer, this can lead to slow announcement of information for participants. But with the increasing number of prospective students, the manual system will slow down service to prospective students. To overcome this, it is necessary to have an online new student admission system that will accelerate the service of prospective students [3].

The website-based PPDB Online is one of the initiatives in the era of industrial revolution 4.0 in the management of new student admissions with a special system designed as a source or center of information and management in the selection process for new student admissions. Each school should have developed this online new student admission system [4]. One of the efforts to improve the PPDB process and improve services to prospective students, we need a system that can carry out the PPDB process that is not limited by places. One technology that can solve this problem is by utilizing website technology [5].

The website-based PPDB system was implemented in 2015 in Purwakarta district. After approximately 5 years of implementing the website-based PPDB Online, there has been no research that discusses the effectiveness of implementing the system. Therefore, it is important to study how the application of the website-based PPDB online system, what factors are the advantages and disadvantages of the system and how the effectiveness of website-based PPDB Online at SMP in Purwakarta Regency.

\section{MethodOLOGY}

This type of research is descriptive qualitative. Sources of data in the study are primary data and secondary data, where primary data were obtained from key informants, namely the Head of the Junior High School Curriculum Section of the Education Office and the District. Purwakarta and the Principals of SMP Negeri 1, SMP Negeri 8, and SMP Negeri 10 in Purwakarta Regency were selected through purposive 
sampling technique, as well as informants, namely students and parents of class VII SMP Negeri 1, SMP Negeri 8, and SMP Negeri 10 Purwakarta district using the accidental technique. sampling. Then secondary data was obtained from documents, PPDB Online 2020 technical instructions, and the internet. Data collection techniques used are observation, interviews, documentation and triangulation [6]. The data analysis technique used in this study was an interactive model consisting of the stages of data collection, data condensation, data presentation and conclusion drawing [7].

\section{RESULTS AND DISCUSSION}

\section{A. Results}

The results showed that the application of website-based online new student admissions has been running effectively and transparently. The implementation is divided into 4 pathways, namely the quota zoning route of $60 \%$, the affirmation pathway of $15 \%$, the transfer path of parents / guardians $5 \%$ and the achievement pathway of $20 \%$. For the achievement pathway, it is divided into 2 tracks, namely achievement of accumulated report scores and achievement of competition results and / or awards in the academic and nonacademic fields of $10 \%$.

However, in its implementation, based on the results of interviews, it was stated that there were still several obstacles, including internet facilities in schools that were still limited, resulting in the PPDB process being hampered. Apart from the facilities, there are also obstacles from school Human Resources (HR), namely the limited school operators who are able to manage websites in this PPDB activity. The lack of socialization is also one of the difficulties faced by most parents of students in registering. It is not clear that the coordinate points in PPDB are based on zoning so that there are some students who are absorbed not according to the distance of their acceptance. Missing data synchronization that must be uploaded by parents of students often occurs so that communication between the operator and the PPDB committee is hampered.

Supporting factors for the PPDB Online System, namely to provide convenience to various parties, both from the school and the community, because the online system makes it easy for people to register at the school of their choice without directly monitoring school because it is enough to do it from their smartphone. Open, honest and fair selection also gives a more distinctive value so that there are no cheats. While the inhibiting factor is that even though the system is practical, there are still not many people who understand the internet or are clueless (technologically illiterate), it will become a separate problem for prospective registrants, which raises suspicion among the public about school parties.

The advantages of implementing Web-based PPDB online are that time is more effective, more transparent and parents / the community can follow developments that occur during PPDB. PPDB results can be conveyed to parents in a short time. Educational services are developing more advanced and based on IT. While the disadvantages of implementing this website-based PPDB online are the limited internet coverage in some areas and the lack of IT support for students who are leveraged students.

To see the effectiveness level of the application of webbased PPDB online, the researchers also conducted an observation study through questionnaires to students and parents. The results of the effectiveness level are as follows:

\section{EFFECTIVENESS OF ONLINE NEW STUNDENT ADMISSION (PPDB) BASED ON WEBSITE}

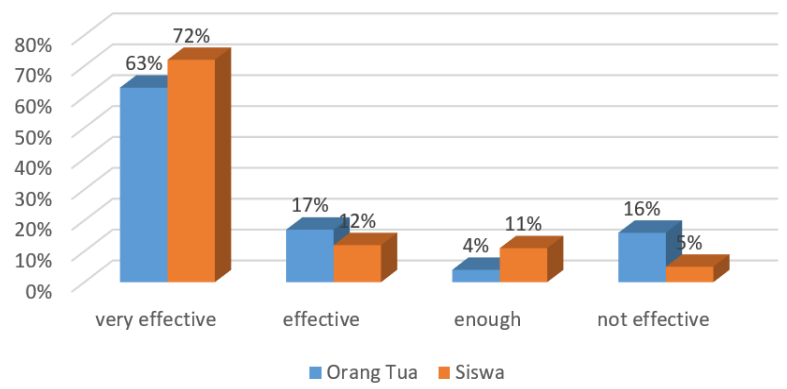

Fig. 1. Effectiveness of Online New Student Admission (PPDB) Based on Website.

Based on the figure 1 above, it can be seen that more than $50 \%$ of parents and students say that the implementation of Web-based PPDB online is very effective. However, there are as many as $16 \%$ of parents of students who say that the system is very ineffective so this is the reason that some parents are still constrained in using the website-based PPDB online system.

\section{B. Discussion}

The provisions for the implementation of Online Student Admissions (PPDB) are based on RI Law Number 17 of 2010 concerning the management of Education in article 74 and article 82 which states about the acceptance of students in educational units which is carried out transparently and objectively [8]. New Student Admissions (PPDB) are implemented through an online mechanism, to make it easier for prospective students to access schools, a zoning system is implemented. This arrangement is expected to make the admissions process take place objectively, accountably, transparently, and without discrimination to improve access to education services $[9,10]$.

Implementation of online PPDB also opens acceptance with the achievement path. The path of achievement is for prospective students who have achievements both academically and non-academically [11]. In implementing PPDB in Purwakarta Regency at the junior high school level, it can run effectively and transparently. This is in accordance with the mandate of the ministry of education and culture that PPDB is 
online, namely through the official PPDB page (website) in each region. Schools organized by the government are required to publicly announce the PPDB implementation process and information, including the requirements, selection, capacity, and results of the admission of new students [12].

To overcome all the obstacles and shortcomings of implementing a website-based PPDB system, both regional and central governments must pay more attention to these problems. Provision of facilities such as computers, software, hardware and internet networks as well as Human Resources (HR) is the key to the success of these activities.

One of the promotional variables in attracting students' attention to register is the school appearance which is represented by the support for the completeness of school infrastructure facilities [13]. Thus, learning support facilities for each subject are analyzed and evaluated, so that they get the advantage to be adjusted to the interests and choices of prospective new students. So, the more complete facilities and infrastructure the school has, the more prospective students will be interested in attending the school $[14,15]$.

Computer-based information systems use the following components such as data, procedures, people, software and hardware, hereinafter referred to as e-government [16]. However, before running a computer-based information system, what should be addressed beforehand is an information system that is not computer-based, because automation will not have a significant effect if the non-computer-based information system is good or bad.

The application of e-government in supporting transparency, effectiveness and accessibility is intended to accelerate the process of interaction between the government and the community where the use is aimed at improving the quality of public services and reviving community activities in order to achieve better welfare, as well as functioning as a portal for information, interactions and transactions. for the government and stakeholders. To ensure the integration of egovernment systems in order to develop transparent and effective public services [17].

\section{CONCLUSION}

Based on the description of the results and the discussion that has been presented, the conclusion that can be drawn is the website-based online new student registration system (PPDB) that has been implemented to make it easier for prospective students to register at SMP which can be done online so as to save time and money, parents also participate as well as being able to control and assist prospective students when registering online. Besides that, it has an impact on improving the performance of the school business process in managing new student data such as a fast and accurate data search process, the recording process is well accommodated and new student admissions reports can be monitored and evaluated periodically by the school.

\section{ACKNOWLEDGMENT}

The author would like to thank the head of the Purwakarta education who has given permission and opportunity for the author to carry out research in Purwakarta district, and has provided support in the form of the required documents. The author also wants to thank the principals and teachers of Public Junior High School 1, State Junior High School 8, and State Junior High School 10 who have been willing to become informants and participants in this study.

\section{REFERENCES}

[1] S. Suswandari, "Sains, Teknologi Dan Pendidikan," J. Teknodik, vol. 14, no. 1, pp. 111-117, 2018.

[2] R. Amin, "Rancang Bangun Sistem Informasi Penerimaan Siswa Baru Pada Smk Budhi Warman 1 Jakarta," JITK (Jurnal Ilmu Pengetah. Dan Teknol. Komputer), vol. 2, no. 2, pp. 113-121, 2017.

[3] D. D. Bhakti, S. M. Putri, I. Nasrulloh, and S. Nurkamilah, "The development of ppdb (admission of new students) application to develop the quality of new students' recapitulation administration in vocational high school bumi cikajang," in Journal of Physics: Conference Series, 2019, vol. 1280, no. 3, p. 32041

[4] D. Kurniadi, A. Mulyani, Y. Septiana, and H. Aulawi, "Estimated software measurement base on use case for online admission system," in IOP Conf. Ser. Mater. Sci. Eng, 2018, vol. 434, no. 1, p. 12062.

[5] J. S. Balasaheb, S. B. Sitaram, W. V. Khushalrao, V. N. Ashok, and M. P. Bhausaheb, "Web Based College Admission System," IJEDR, 2014.

[6] V. A. Lambert and C. E. Lambert, "Qualitative descriptive research: An acceptable design,” Pacific Rim Int. J. Nurs. Res., vol. 16, no. 4, pp. 255-256, 2012

[7] M. B. Miles and A. M. Huberman, Qualitative data analysis: An expanded sourcebook. sage, 1994.

[8] Undang-undang Republik Indonesia Nomor 17 Tahun 2010, tentang Pengelolaan Pendidikan. 2010.

[9] C. W. Hoerudin, "Evaluation of new student admission policy based on zonation system in Bandung City," JISPO J. Ilmu Sos. dan Ilmu Polit., vol. 9, no. 2, pp. 351-361, 2019.

[10] K. Põder, T. Lauri, and A. Veski, "Does school admission by Zoning affect educational inequality? A study of family background effect in Estonia, Finland, and Sweden," Scand. J. Educ. Res., vol. 61, no. 6, pp. 668-688, 2017.

[11] H. A. Lestari and W. Rosdiana, "Implementasi Kebijakan Penerimaan Peserta Didik Baru (PPDB) di SMA Negeri 4 Kota Madiun Tahun 2017," J. Mhs. Unesa, vol. 6, no. 5, 2018.

[12] A. C. Purnomo, B. Pramono, and F. P. Oganda, "Design of Information System in Admission of New Students Based on Web in SMK Al Amanah," Aptisi Trans. Manag., vol. 3, no. 2, pp. 159-167, 2019.

[13] S. N. Khan and I. M. Qureshi, "Impact of promotion on students' enrollment: A case of private schools in Pakistan," Int. J. Mark. Stud., vol. 2, no. 2, pp. 267-274, 2010

[14] M. F. Setiawan and M. P. Sutama, "Pengelolaan Penerimaan Peserta Didik Baru (PPDB) Pada SD Muhammadiyah Program Khusus Banyudono." Universitas Muhammadiyah Surakarta, 2018.

[15] N. U. R. A. MIRA, "Efektivitas Penerimaan Peserta Didik Baru (Ppdb) Online Di Dinas Pendidikan Dan Kebudayaan Kota Makassar.” 2016.

[16] N. W. Karmini, "Discursusing of the zonation system in accepting new student in 2018: Case study in Denpasar city," 2020. 